\title{
JAKĄ ROLĘ ODGRYWAJĄ ZASOBY ELEKTRONICZNE W NAUCE JEZZYKA POLSKIEGO JAKO OBCEGO/ODZIEDZICZONEGO? WYNIKI BADAŃ ANKIETOWYCH ${ }^{1}$
}

\begin{abstract}
Słowa kluczowe: język polski jako obcy, język polski jako odziedziczony, strategie uczenia się, Internet, aplikacje mobilne, Generacja Z, tubylec internetowy

Streszczenie. Artykuł powstał na podstawie wyników anonimowej ankiety internetowej przeprowadzonej w międzynarodowej grupie uczących się języka polskiego jako obcego/odziedziczonego. Pokazuje, czy i jakich zasobów elektronicznych uczący się używają do nauki gramatyki, słownictwa, ortografii i wymowy. Definiuje rolę, jaką pełni lektor języka polskiego przy strategii uczenia się przez Internet.
\end{abstract}

\section{WPROWADZENIE}

Większość osób obecnie uczących się języka polskiego jako obcego (lub odziedziczonego) należy już do Generacji Z, czyli tzw. tubylców internetowych (digital natives). Wykorzystanie zasobów internetowych jest więc dla naszych uczniów rzeczą naturalną. Poniższe badania mają odpowiedzieć na pytanie, czy współcześni uczący się rzeczywiście preferują naukę przy użyciu zasobów online, a nie tradycyjnych podręczników. Jaki jest stosunek uczącego się do owych narzędzi, czyli stron internetowych i mobilnych aplikacji wspomagających naukę języka oraz jaką rolę odgrywają one na lektoratach języka polskiego jako obcego? Dzięki opisanej poniżej próbie ankietowej artykuł stanowi swoisty miniprzegląd aktualnie używanych zasobów elektronicznych. Zawiera także informacje o preferowanych strategiach uczenia się i nauczania języka polskiego jako obcego.

*nataliekosch@hotmail.com, Uniwersytet Warszawski, Centrum Języka Polskiego i Kultury Polskiej dla Cudzoziemców Polonicum, ul. Krakowskie Przedmieście 26/28, 00-927 Warszawa,

${ }^{1} \mathrm{Na}$ podstawie ankiety: Czy używasz zasobów internetowych lub aplikacji do nauki języka polskiego jako obcego/odziedziczonego?. 


\section{RESPONDENCI}

$\mathrm{Na}$ ankietę odpowiedziało 52 respondentów (39 kobiet i 13 mężczyzn), uczących się języka polskiego jako obcego lub odziedziczonego w Polce i poza jej granicami. Ankietowani pochodzą z: Austrii, Białorusi, Chin, Gruzji, Hiszpanii, Kazachstanu, Niemiec, Polski², Rosji, Słowacji, Syrii, Szwajcarii, Turkmenistanu, Ukrainy, Uzbekistanu i Włoch. Wiek respondentów: poniżej 17 lat (3 respondentów), 18-20 lat (11 respondentów), 21-29 lat (13 respondentów) i 30-39 lat (13 respondentów). Wszyscy uczą się na lektoratach j. polskiego, studiują filologię polską za granicą lub uczą się indywidualnie języka i znajdują na różnych poziomach jego znajomości. Wymienieni awizowali znajomość języka polskiego następująco:

Wykres 1. Jak dtugo uczysz się języka polskiego jako obcego/odziedziczonego?

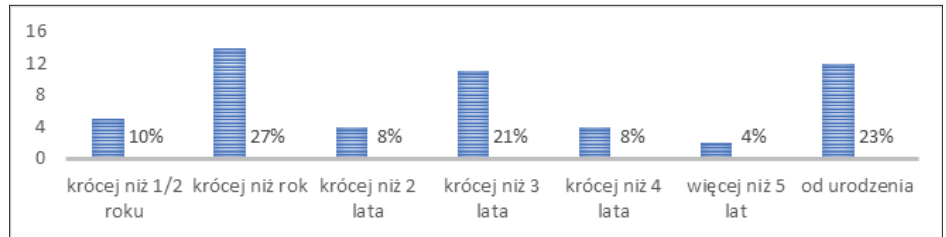

Źródło: opracowanie własne

\section{PRZEBIEG BADAŃ}

Badania przeprowadzono w formie anonimowej ankiety internetowej. Obejmowała ona 34 pytania otwarte i zamknięte (w tym metryczkę badania). Została stworzona w trzech językach (polskim, angielskim i niemieckim), aby umożliwić uczącym się na każdym poziomie znajomości polszczyzny swobodne wypełnienie ankiety. Dotarła do uczestników badania drogą elektroniczną i była dostosowana również do wypełnienia z użyciem urządzeń mobilnych. Rozpowszechniono ją dzięki uprzejmości lektorów JPJO w Polsce i za granicą. Ankietę przeznaczono głównie dla respondentów dorosłych, z nieograniczonym ${ }^{3}$ dostępem do Internetu. Pytania ogniskowały się głównie wokół stosunku uczącego się do stron i aplikacji internetowych w procesie nauki języka polskiego jako obcego. Odnosiły się do charakterystyki korzystania ze stron i aplikacji mobilnych w trakcie tej nauki:

${ }^{2}$ Mowa o osobach polskiego pochodzenia żyjących poza Polską.

${ }^{3}$ Przez ograniczenia rozumiałam np. regulowanie przez rodziców czasu korzystania z Internetu lub zakaz kupowania czy ściągania aplikacji na urządzenia mobilne. 
udoskonalaniu wiedzy gramatycznej, przyswajaniu lub uczeniu się słownictwa, zasad ortograficznych i fonetyki. Prowadziły do kluczowego zagadnienia - czy lektorzy języka polskiego używają stron lub aplikacji przeznaczonych do nauczania języka polskiego w procesie dydaktycznym.

\section{STOSUNEK UCZĄCYCH SIĘ DO MOŻLIWOŚCI KORZYSTANIA $Z$ INTERNETU W NAUCE JPJO}

Oprócz dwóch respondentów wszyscy ankietowani deklarowali używanie stron internetowych do nauki języka polskiego. Największą popularnością cieszą się słowniki internetowe. Jako najczęściej używane wymieniono:

Wykres 2. Użycie stowników internetowych przez respondentów

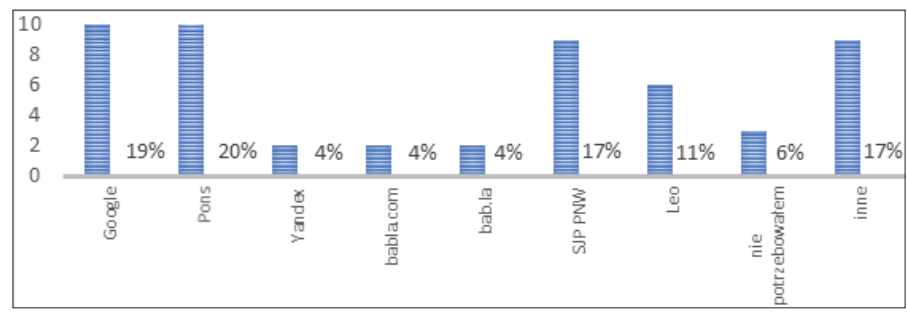

Źródło: opracowanie własne

Największą popularnością cieszy się słownik PONS. Zarówno wersja internetowa, jak i mobilna posiadają funkcję wypowiadania słów. Uczący się ma więc możliwość nie tylko przeczytania poszukiwanego słowa, ale też usłyszenia poprawnej wymowy. Na drugim miejscu znajduje się thumacz Google, ankietowani podali, iż używają go też do tłumaczeń dłuższych wypowiedzi. Na trzecim miejscu figuruje $S J P P W N$. Wśród niemieckojęzycznych ankietowanych wymieniano często $L E O$. Podobnie jak PONS jest dostępny jako aplikacja i posiada funkcję wypowiadania słów. Ankietowani piszący cyrylicą cenią sobie słownik Yandex. Wśród innych rzadziej wymienionych znajdują się słowniki podane tutaj w kolejności alfabetycznej: Dictcc, E-bratanki, Glosbe, Translatica, Lingea, Lingvo, Wikisłownik.

Przy pytaniu: Czy używałeś/używałaś stron internetowych (nie dotyczy mobilnych aplikacji) do nauki gramatyki języka polskiego? odpowiedzi należy podzielić na dwie polaryzujące się frakcje: na nieznacznie mniej niż połowę respondentów, którzy kompletnie odrzucają naukę gramatyki języka polskiego za pomocą Internetu i na nieco więcej niż połowę tych, którzy chętnie korzystają z rożnych źródeł internetowych dla przyswojenia lub pogłębienia wiedzy na tematy gramatyczne. Przeciwnicy gramatycznych poradników językowych w Internecie preferują wła- 
sne, zazwyczaj już sprawdzone gramatyki języka polskiego. Inni są przekonania, iż samej gramatyki można się nauczyć na lektoracie lub że pogłębianie wiedzy poza lektoratem nie jest potrzebne. Zwłaszcza osoby dwujęzyczne podawały, że komunikując się z rodziną przy użyciu aplikacji WhatsApp, uczą się wystarczająco dużo gramatyki lub iż przyswajanie gramatyki jest im niepotrzebne. Dwudziestu siedmiu z pięćdziesięciu dwóch respondentów potwierdziło, że korzysta z Internetu mimo problemów z poprawnością gramatyczną materiałów zamieszczanych na niektórych stronach internetowych. Inne strategie radzenia sobie z trudnościami gramatycznymi lub przyswajania nowych zagadnień prowadzą od oglądania filmików edukacyjnych na YouTube, a także do oglądania przypadkowych stron - poprzez kwerendę w wyszukiwarkach. Najczęściej wymienianymi stronami są: www.mowicpopolsku.com, www.pl.glosbe.com/pl/ku/polska i polskinawynos.com - strony te oferują poza ćwiczeniami leksykalnymi, gramatycznymi i na rozumienie ze słuchu na poziomach A1-C1 artykuły ze słowniczkami, testy i filmiki do nauki JPJO. Kolejno wymieniano strony dedykowane uczniom i studentom, takie jak: sciaga.pl, bryk.pl lub strony internetowe specjalizujące się w nauczaniu języków obcych w formie online. Strony te oferują słowniki, gramatykę i ćwiczenia poszczególnych zagadnień. Wymieniono: O bohan (www.bohan.pl $)^{4}, w w w . a z t e-$ kium.pl $l^{5}$,www.bab.la (słownik), www.duolingo.com ${ }^{6}$. Na portalu YouTube uczący się języka polskiego jako obcego wolą filmiki specjalnie przeznaczone do nauki gramatyki. Wikipedia w różnych swoich odmianach, jak Wiktonary i Wikisłownik, też pojawiła się w wypowiedziach ankietowanych. Tylko dwóch respondentów podało, że nie zna żadnych stron do nauki gramatyki online. Pytanie o to nie było zresztą obowiązkowe, więc nie każdy podzielił się swoimi doświadczeniami dotyczącymi stron przydatnych dla nauki gramatyki języka polskiego.

Przy pytaniu: Czy używałeś/używataś stron internetowych (nie dotyczy mobilnych aplikacji) do nauki stownictwa (np. fiszki online, specjalne strony do nauki i automatyzacji słownictwa)? wykres odpowiedzi wygląda następująco:

Wykres 3. Uzycie stron internetowych do nauki i automatyzacji słownictwa

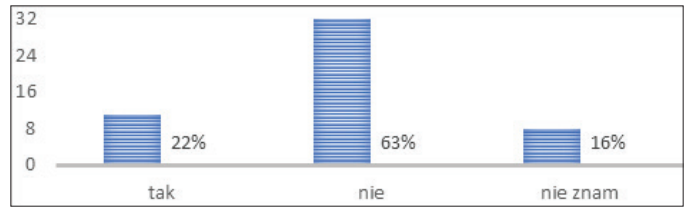

Źródło: opracowanie własne

Znacząca większość ankietowanych nie używa lub nie zna stron do nauki słownictwa. Łączna suma to 79\% (ani wiek, ani płeć nie odgrywają tutaj znaczą-

${ }^{4}$ Bohan Online to słownik chińsko-polski oraz polsko-chiński z interfejsem użytkownika dostępnym w trzech językach.

${ }^{5}$ Darmowa strona edukacyjna.

${ }^{6}$ Platforma do nauki języków obcych. 
cej roli). W odpowiedziach ankietowanych korzystających z programów przystosowanych do automatyzacji i przyswajania słownictwa polskiego wymieniono ponownie strony: www.polskinawynos.com, www.mowicpopolsku.com oraz po raz pierwszy Polski z Aniq ${ }^{7}$. Pojawiły się również takie strony, jak: www.bab.la, www. duolingo.com, www.quizlet.com ${ }^{8}$ oraz www.vocabularytrainer.net. Ankietowani, którzy nie korzystają z powyżej wymienionych stron, cenią sobie bardziej rozmowy z natywnymi użytkownikami języka (rodzice i znajomi), preferują autentyczne źródła, jak książki, seriale, filmy i gazety, filmiki na YouTube oraz powołują się na zadania domowe zlecone przez lektorów (czytanie artykułów i tekstów na lektoracie). Wśród odpowiedzi pojawiły się jasne komunikaty, iż ankietowani po wypróbowaniu stron nie byli do nich przekonani.

Przy pytaniu: Czy używateś/używałaś stron internetowych (nie dotyczy mobilnych aplikacji) do nauki ortografii? 23\% ankietowanych podało, iż używają zasobów elektronicznych, takich jak SJP PWN i Wiktionary. Ankietowani wolą uczyć się ortografii z lektorem i za pomocą książek. Wymieniono tu książkę specjalnie przeznaczoną do nauki ortografii Nie ma róży bez kolców autorstwa Ewy Lipińskiej (2017).

Wykres 4. Uzycie stron internetowych do nauki ortografii

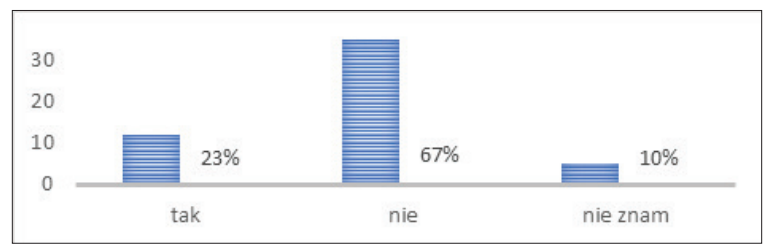

Źródło: opracowanie własne

Przy pytaniu: Czy używateś/używałaś stron internetowych (nie dotyczy mobilnych aplikacji) do nauki poprawnej wymowy? 71\% ankietowanych deklaruje, że nie używa lub nie zna odpowiednich stron, za pomocą których mogliby poprawić nie tylko wymowę języka polskiego, ale także percepcję. Część respondentów deklaruje, iż nie zastanawiała się nad zastosowaniem strategii uczenia się wymowy przez Internet, w związku z czym nie szukała odpowiednich stron. Inni podają, iż wolą rozmowy z rodzimymi użytkownikami języka, odpowiadając, że zdają się na ćwiczenia podczas lektoratów lub na ćwiczenia zadane przez lektorów, korzystają także ze stron udostępnionych przez tych ostatnich. Tak jak w przypadku nauki słownictwa, pojawiają się tutaj twierdzące odpowiedzi respondentów, którzy ćwiczą raczej percepcję niż docelowo wymowę za pomocą filmików na YouTube i poprzez oglądanie wiadomości po polsku. Inni (w większości osoby dwujęzyczne) uznają, że ćwiczenie wymowy jest zbędne. Uczący

\footnotetext{
${ }^{7}$ Kanał na YouTube Anny Rabczuk z Centrum Polonicum Uniwersytetu Warszawskiego o gramatyce języka polskiego.

${ }^{8}$ Proste narzędzia dydaktyczne w formie online.
} 
się, którzy ćwiczą wymowę powołują się na strony udostępnione przez platformy uniwersyteckie, na stronę: www.wymowapolska.pl $l^{9}$ i ponownie na thumacza Google i Duolingo.

Wykres 5: Uzycie stron internetowych do nauki poprawnej wymowy

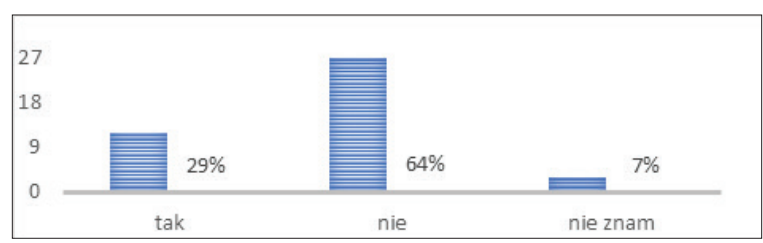

Źródło: opracowanie własne

Przy pytaniu: Czy używateś/używałaś stron internetowych do innych celów nauki języka polskiego niz poprzednio wymienione? ankietowani często odpowiadali, iż używają Internetu do wyszukiwania gotowych fraz i wypowiedzi np. do napisania recenzji lub rozprawki. Większość podaje, że Internet zapewnia im cenną możliwość oglądania seriali i filmów oraz polską grę komputerową Wiedźmin.

\section{STOSUNEK UCZĄCYCH SIE DO MOBILNYCH APLIKACJI POMOCNYCH W NAUCE JPJO}

Wymienione wyżej pytania, dotyczące korzystania ze stron internetowych w celu nabywania poszczególnych sprawności językowych, powtórzono w rozpoznaniu użycia aplikacji mobilnych na urządzeniach przenośnych. Wyniki badań pokazują, że jeszcze rzadziej niż Internetu uczący się używają mobilnych aplikacji przeznaczonych do nauki języka polskiego jako obcego.

Przy pytaniu: Czy używałeś/używałaś mobilnych aplikacji na smartfony/tablety do nauki gramatyki języka polskiego? 72\% ankietowanych odpowiedziało, że nie lub że nie zna aplikacji do nauki języka polskiego. Zdaniem ankietowanych aplikacje nie nadążają za gramatykami książkowymi, wyróżniającymi się kompleksowością zagadnień i przykładami. Respondenci preferują je, ponieważ wybór dobrej gramatyki języka polskiego jest sam w sobie wyzwaniem. Inni podają ponownie, iż materiał omawiany na lektoracie zupełnie im wystarczy, a osoby pochodzące $\mathrm{z}$ rodzin polskich cenią sobie możliwość prowadzenia korespondencji przez WhatsApp. 28\% korzystających z aplikacji potwierdziło pracę z (kolejność alfabetyczna): Diki (słownik), Duolinguo, Leo, SpeakASP ${ }^{10}$, thumaczem Google, Ucz się polskiego ${ }^{11}$, Vocabulary trainer.

\footnotetext{
${ }^{9}$ Strona z ćwiczeniami wspomagającymi percepcję i wymowę języka polskiego.

${ }^{10}$ Platforma do nauki języków obcych.

${ }^{11}$ Kanał na YouTube: Wiedza o Polsce Liliany Sosnowskiej.
} 
Wykres 6. Użycie mobilnych aplikacji na smartfony/tablety do nauki gramatyki języka polskiego

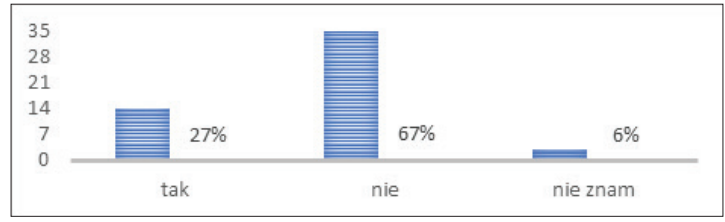

Źródło: opracowanie własne

Przy pytaniu: Czy używałeś/używałaś mobilnych aplikacji na smartfony/tablety do nauki stownictwa (np. fiszki online, specjalne aplikacje do nauki i automatyzowania stownictwa)? niecałe $30 \%$ badanych deklaruje, że korzysta z oferowanych aplikacji. Używają: Duolingo, Leo, Memrise ${ }^{12}$, Quizlet, Radio, russko-polckii stownik (pisane cyrylicą), www.support.ttdictionary.com (kolejność alfabetyczna). $73 \%$ respondentów, oprócz wymienionych w poprzednim pytaniu powodów nieużywania aplikacji podaje, że do nauki słownictwa stosują tradycyjne fiszki, wolą uczyć się za pomocą piosenek, filmów i seriali. Odpowiadają, że nie ufają aplikacjom, ponieważ pojawiają się w nich błędy i nieścisłości. Część ankietowanych nie wie o istnieniu aplikacji do nauki i automatyzacji słownictwa polskiego.

Wykres 7. Użycie mobilnych aplikacji na smartfony/tablety do nauki stownictwa

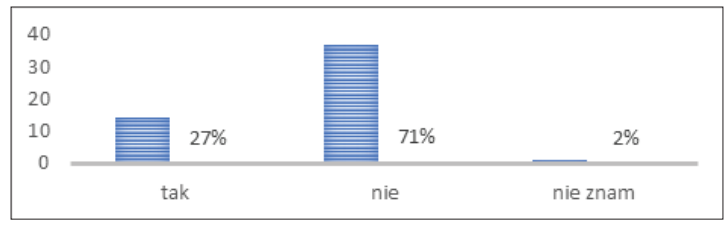

Źródło: opracowanie własne

Przy pytaniu: Czy u̇̇ywałeś/używałaś mobilnych aplikacji na smartfony/tablety do nauki ortografii? 83\% respondentów stwierdza, że nie lubi, nie używa, nie zna lub nigdy nie interesowało się takimi aplikacjami. Inni oznajmiają, że nie uczą się w tak nowoczesny sposób. Cenią korekty lektorów i natychmiastowe informacje zwrotne na lektoratach. Ponownie wymieniają książki jako preferowaną pomoc przy uczeniu się ortografii. Użytkownicy aplikacji podają, iż pracują z: Duolinguo, Leo i Quizlet.

Wykres 8. Użycie mobilnych aplikacji na smartfony/tablety do nauki ortografii

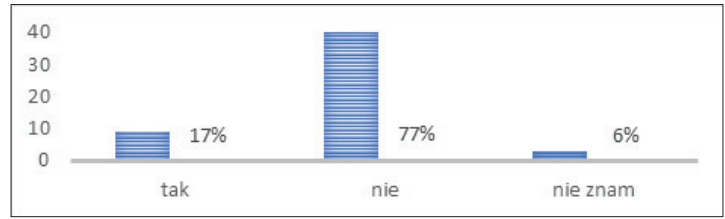

Źródło: opracowanie własne

${ }^{12}$ Proste narzędzia dydaktyczne w formie online. 
Przy pytaniu: Czy używateś/używałaś mobilnych aplikacji na smartfony/tablety do nauki poprawnej wymowy? 85\% pytanych odpowiedziało, że nie używa aplikacji do poprawy własnej wymowy. Osoby z językiem polskim jako odziedziczonym podają, iż nie czuli nigdy potrzeby uczenia się wymowy. Pojawiły się głosy negatywnie oceniające jakość nagrań - według ankietowanych nagrania brzmią one sztucznie. Inni przyznają, że nigdy nie słyszeli o istnieniu takich aplikacji. Wśród używanych przez ankietowanych (15\%) znajdują się: Duolingo, Leo, Lubię polski, strony uniwersyteckie.

Wykres 9. Użycie mobilnych aplikacji na smartfony/tablety do nauki poprawnej wymowy

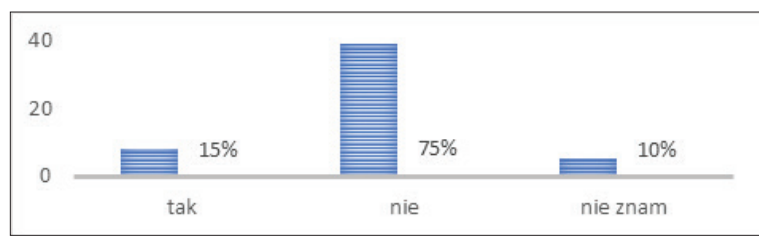

Źródło: opracowanie własne

\section{OBECNOŚĆ INTERNETU I MOBILNYCH APLIKACJI NA LEKTORATACH JPJO}

Jednym z elementów badania było także pytanie o to, skąd uczący się języka polskiego jako obcego znają strony internetowe lub mobilne aplikacje. Znakomita większość podaje, iż znalazła strony/aplikacje dzięki własnej inicjatywie - zwracali się o pomoc do znajomych i do lektorów języka polskiego. 14\% podało brak zainteresowania, a 7\% znalazło aplikacje przez przypadek.

Wykres 10. Źródła znajomości stron internetowych / mobilnych aplikacji do nauki języka polskiego jako obcego?

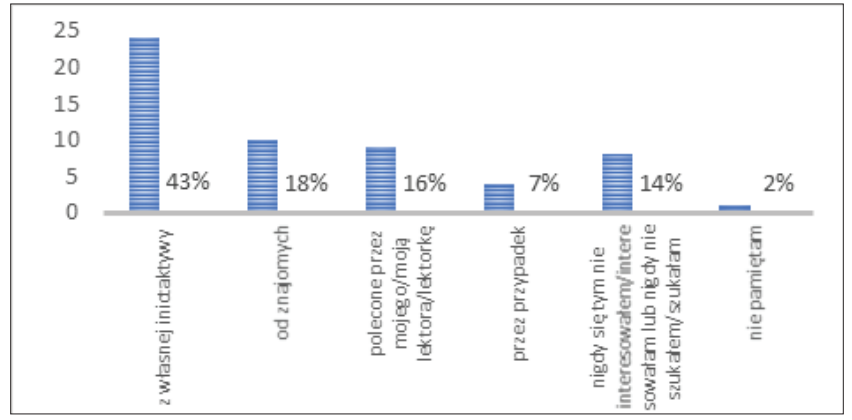

Źródło: opracowanie własne 
Na większości lektoratów (61\%) nauczyciele języka polskiego używają następujących narzędzi internetowych lub tylko przedstawiają je kursantom: Google, kahoot $^{13}$, ćwiczenia online do podręcznika Krok po kroku (Stempek, Stelmach, Szymkiewicz2011), platformy uniwersyteckie, Polskinawynos,polskipopolsku.pl, Quizlet, słownik SJP, Wielki słownik języka polskiego, wymowapolska.pl.

Wykres 11. Prezentacja stron internetowych lub mobilne aplikacje do nauki języka polskiego jako obcego przez lektorów na zajęciach?

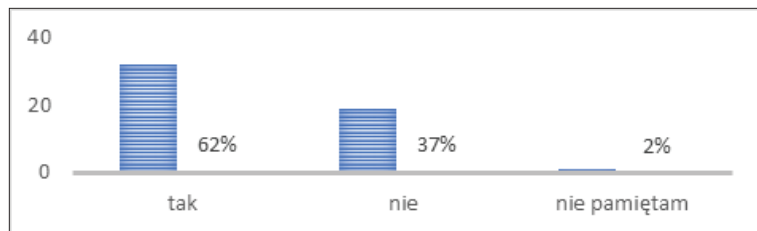

Źródło: opracowanie własne

\section{PODSUMOWANIE}

Z przeprowadzonej analizy wynika, iż Internet i mobilne aplikacje do nauki JPJO, pomimo iż cieszą się popularnością ${ }^{14}$, spotykają się też z dużą ostrożnością większości uczących się. Ankietowani odpowiadali na pytanie: Jak często używasz zasobów elektronicznych / mobilnych aplikacji do nauki języka polskiego jako obcego? w skali od 1 (bardzo rzadko) do 5 (bardzo często) jak poniżej:

Wykres 12. Częstotliwość użycia zasobów elektronicznych / mobilnych aplikacji do nauki języka polskiego jako obcego

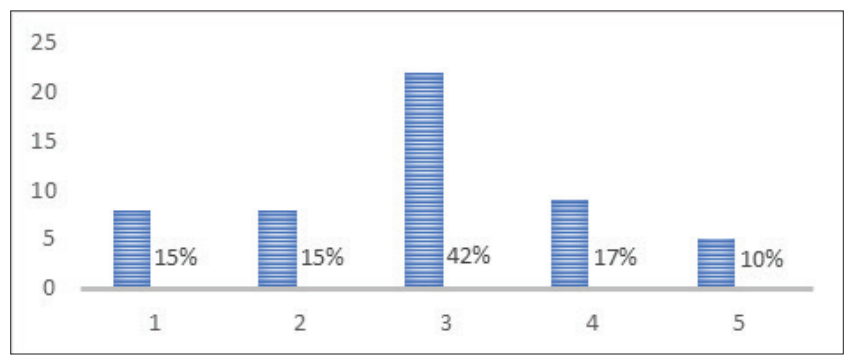

Źródło: opracowanie własne

Stwierdzają, iż nie znają aplikacji lub sprawdzonych stron. Podkreślają to też wyniki badań, wskazujące na mały zakres przedstawionych źródeł wspomagających indywidualne uczenie się online. Porównując liczne podawane przez uczących się

${ }^{13}$ Platforma przeznaczona do tworzenia gier edukacyjnych.

${ }^{14}$ Strony internetowe większą. 
przykłady, dzięki jakim stronom można wesprzeć proces nauczania online poza lektoratami, z przykładami podawanymi przez lektorów (informacje ankietowe), dostrzega się widoczną różnicę ilościową. Nauczyciele nie przedstawiają uczącym się pełnej oferty źródeł, z których mogliby czerpać wiedzę poza lektoratami. Kursanci nie mają zaufania do źródeł internetowych, korzystają z przypadkowo znalezionych stron lub aplikacji, częściowo nawet nie mają świadomości, iż istnieją strony lub aplikacje specjalne dostosowane do ćwiczenia i uczenia się poszczególnych sprawności - percepcji, wymowy, słownictwa, gramatyki lub ortografii. Uczenie się języka obcego/odziedziczonego w środowisku rodzinnym lub grupie znajomych i przyjaciół posługujących się językiem docelowym uczącego się jest optymalną, ale nie dla każdego realną sytuacją. Uczący się musi wiedzieć, gdzie i jak może pracować nad swoimi indywidualnymi problemami językowymi i tu rola lektora języka przekształca się w rolę doradcy (tzw. coacha językowego). Pytania o to: Gdzie dokładnie masz braki, co już umiesz, z czym masz problemy i czemu je masz? stanowią istotę tej funkcji. Następnie pojawiać się powinno wzmocnienie procesu decyzyjnego, czyli sformułowania: Jaka metoda chce się nauczyć, jakie mam cele? Dalej - opracowanie alternatywnych metod postąpienia - jeżeli to nie działa, to co moge innego zrobić? Na zakończenie powinno się przejść do utworzenia długotrwałej strategii nauki samodzielnej. Uczący się musi mieć świadomość, jakie metody uczenia się istnieją i jak lub - w przypadku stron internetowych i aplikacji - gdzie mogę się nauczyć języka polskiego poza lektoratem. Rzecz jasna, że uczenie się w formie online nie odpowiada wszystkim typom sensorycznym, lecz dobry coach językowy przedstawiający wszystkie możliwe metody, przygotowuje ucznia do przyswajania najnowszej wiedzy, również tej wynikającej z rozwoju technologii.

\section{BIBLIOGRAFIA}

Benson P., 2001, Teaching and Researching Autonomy in Language Learning, Londyn.

Chamlot A., O'Malley J., 1994, The CALLA Handbook. Implementing the Cognitive Academic Language Learning Approach, Harlow.

Gruza D., Pabiańczyk A., 2016, Język polski 2.0 - zastosowanie nowoczesnych technologii $w$ nauczaniu języka polskiego, [online] http://www.efundacja.org/j281zyk-polski-20.html [14.06.2018].

Kleppin K., Spänkuch E., 2014, Fremdsprachenlerner beraten / coachen - Was hat das mit Lehren zu tun? Ein Reflexionsangebot, [online] https://periodicals.narr.de/index.php/flul/article/download/2171/2072 [14.06.2018].

Legutke M., Thomas H., 1991, Process and Experience in the Language Classroom, Londyn.

Lipińsk E., 2017, Nie ma róży bez kolców. Ćwiczenia ortograficzne dla cudzoziemców. Poziom średniozaawansowany. Poziom B1-B2, Kraków.

Maciaszczyk S., 2009, Zajęcia e-learningowe, w: Skuteczna nauka języka obcego. Struktura i przebieg zajęć językowych, Warszawa.

Marzano R., 2012, Sztuka i teoria skutecznego nauczania, Warszawa.

Stempek I., Stelmach A., Szymkiewicz S., 2011, Polski. Krok po kroku, Kraków. 


\section{ANEKS \\ ANKIETA: CZY UŻYWASZ ZASOBÓW INTERNETOWYCH LUB APLIKACJI DO NAUKI POLSKIEGO JAKO OBCEGO/ODZIEDZICZONEGO?}

1. Wiek:

2. Wykształcenie:

3. Czy uczysz się ...

4. Jak długo uczysz się języka polskiego jako obcego/odziedziczonego?

5. W jakim kraju uczysz się aktualnie języka polskiego jako obcego/odziedziczonego?

6. Kraj pochodzenia:

7. Czy używałeś/używałaś Internetu do nauki języka polskiego jako obcego/odziedziczonego (np. słowniki elektroniczne, gramatyki elektroniczne, aplikacje itd.)

8. Czy używałeś/używałaś słowników internetowych?

9. Jeżeli używasz słowniki internetowe, to jakie? / Jeżeli nie, to dlaczego nie?

10. Czy używałeś/używałaś stron internetowych (nie dotyczy mobilnych aplikacji) do nauki gramatyki języka polskiego?

11. Jeżeli używasz stron internetowych do nauki gramatyki języka polskiego, to jakich? / Jeżeli nie, to dlaczego nie?

12. Czy używałeś/używałaś stron internetowych (nie dotyczy mobilnych aplikacji) do nauki słownictwa (np. fiszki online, specjalne strony do nauki i automatyzowania słownictwa)?

13. Jeżeli używasz stron internetowych do nauki słownictwa to jakich? / Jeżeli nie, to dlaczego nie?

14. Czy używałeś/używałaś stron internetowych (nie dotyczy mobilnych aplikacji) do nauki ortografii?

15. Jeżeli używasz stron internetowych do nauki ortografii, to jakich? / Jeżeli nie, to dlaczego nie?

16. Czy używałeś/używałaś stron internetowych (nie dotyczy mobilnych aplikacji) do nauki poprawnej wymowy?

17. Jeżeli używasz stron internetowych do nauki poprawnej wymowy, to jakich? / Jeżeli nie, to dlaczego nie?

18. Czy używałeś/używałaś stron internetowych do innych celów nauki języka polskiego niż poprzednio wymienione?

19. Czy używałeś/używałaś mobilnych aplikacji na smartfony/tablety do nauki gramatyki języka polskiego?

20. Jeżeli używasz mobilnych aplikacji do nauki gramatyki języka polskiego, to jakich? / Jeżeli nie, to dlaczego nie?

21. Czy używałeś/używałaś mobilnych aplikacji na smartfony/tablety do nauki słownictwa (np. fiszki online, specjalne aplikacje do nauki i automatyzowania słownictwa)?

22. Jeżeli używasz mobilnych aplikacji do nauki słownictwa języka polskiego, to jakich? / Jeżeli nie, to dlaczego nie?

23. Czy używałeś/używałaś mobilnych aplikacji na smartfony/tablety do nauki ortografii?

24. Jeżeli używasz mobilnych aplikacji do nauki ortografii, to jakich? / Jeżeli nie, to dlaczego nie?

25. Czy używałeś/używałaś mobilnych aplikacji na smartfony/tablety do nauki poprawnej wymowy? 
26. Jeżeli używasz mobilnych aplikacji do nauki poprawnej wymowy, to jakich? / Jeżeli nie, to dlaczego nie?

27. Czy używałeś/używałaś mobilnych aplikacji na smartfony/tablety do innych celów nauki języka polskiego niż poprzednio wymienione?

28. Skąd znasz strony internetowe / mobilne aplikacje do nauki języka polskiego jako obcego?

29. Czy lektor/lektorka języka polskiego przedstawiał/przedstawiała ci strony internetowe lub mobilne aplikacje do nauki języka polskiego jako obcego na zajęciach?

30. Czy lektor/lektorka języka polskiego używa stron internetowych lub mobilnych aplikacji do nauczania języka polskiego jako obcego?

31. Jeżeli twój/twoja lektor/lektorka języka polskiego używa stron internetowych lub mobilnych aplikacji do nauczania języka polskiego jako obcego, to jakich?

32. Jak często używasz zasobów elektronicznych / mobilnych aplikacji do nauki języka polskiego jako obcego?

Natalie Kosch

\section{WHAT ROLE DO ELECTRONIC RESOURCES PLAY IN LEARNING POLISH AS A FOREIGN/SECOND LANGUAGE? THE RESULTS OF A SURVEY}

Keywords: Polish as a foreign language, Polish language as second language, learning strategies, Internet, mobile applications, generation Z, digital native, role of the Polish teacher

Abstract. The article is based on the results of an anonymous online survey conducted in an international group of learners of Polish as a foreign/second language. It illustrates if and which electronic learning platforms learners currently use to learn Polish grammar, vocabulary, spelling and pronunciation andhow Polish language teacher plays an important role in using the Internet in the process of learning. 